\title{
PENGARUH HARDINESS DAN RELIGIUSITAS TERHADAP JOB STRESS PEDAGANG KAKI LIMA
}

\author{
Abdul Muis cee.muiz@yahoo.com \\ Fakultas Psikologi UIN Sarif Hidayatullah Jakarta 2014
}

\begin{abstract}
This study was conducted to determine the effect of religiosity on the job hardiness and stress hawkers. The author theorizes that the variable hardiness is a commitment, control, challenge and variable religiosity that is, the daily spiritual experience, meaning, values, beliefs, forgiveness, private religious practice, religious/spiritual coping, religious support, religious/spiritual history, organizational religiousness, commitment, and religious preference job stress affect street vendors.

This study uses a quantitative approach to the multiple regression analysis. Sample of 145 people hawkers taken with non-probability sampling techniques. The authors use of the raw scale and modified as additional data collection instruments, namely the scale of job stress, hardiness scale, and scale multidimensional measurement of religiousness/spirituality for use in health.

The results of this study indicate that hardines dimension (commitment, control and challenge) influence to job stress hawkers though not significantly. The twelve dimensions of religiosity only to the four dimensions that influence significantly the religious/spiritual history, commitment, organizational religiousness, religious preference and variables that influence but not significantly, dailly spiritual experience, maining, values, beliefs, forgiveness, private religious practice, religious/spiritual coping, and religious support.
\end{abstract}

Keywords: hardiness, religiosity, job stress

\begin{abstract}
Abstrak
Penelitian ini bertujuan untuk membuktikan pengaruh hardiness dan religiusitas terhadap job stress pedagang kaki lima. Penulis berteori bahwa variabel hardiness yakni komitmen, kontrol, tantangan dan variabel religiusitas yakni, daily spiritual experience, meaning, values, beliefs, forgiveness, private religious practice, religious/spiritual coping, religious support, religious/spiritual history, organizational religiousness, commitment, dan religious preference mempengaruhi job stress.

Penelitian ini menggunakan analisis regresi berganda. Sampel 145 orang pedagang diambil dengan teknik non-probability sampling. Alat ukur menggunakan skala baku dan memodifikasi instrumen, yaitu skala job stress, skala hardiness, dan skala multidimensional measurement of religiousness/spirituality for use in health.

Hasil penelitian membuktikan ada pengaruh dimensi hardiness (komitmen, kontrol, dan tantangan) terhadap job stress meskipun tidak signifikan. Empat dimensi religiusitas berpengaruh secara signifikan yakni religious/spiritual history, commitment, organizational religiousness, dan religious preference. Variabel dailly spiritual experience, maining, values, beliefs, forgiveness, private religious practice, religious/spiritual coping, dan religious support berpengaruh tetapi tidak signifikan.
\end{abstract}

Kata kunci : hardiness, religiusitas, job stress 


\section{LATAR BELAKANG}

Di dalam kehidupan yang semakin kompleks, setiap orang selalu berusaha menciptakan dan mencapai kebahagian hidup. Sumber daya manusia yang berkualitas dituntut agar dapat mencapai keberhasilan seoptimal mungkin untuk meningkatkan produktivitasnya demi tercapai kebahagiaan hidup. Kehidupan semakin hari menyajikan banyak hal baik kesulitan, tantangan maupun ketatnya persaingan hidup. Bagi masyarakat pada era industrialisasi saat ini, bekerja merupakan suatu aspek kehidupan yang sangat penting. Bagi masyarakat modern bekerja merupakan suatu tuntutan yang mendasar, baik dalam rangka memperoleh imbalan berupa uang atau jasa, ataupun dalam rangka mengembangkan dirinya. Karena pada kenyataannya, sebagian pekerjaan cenderung memiliki konotasi paksaan, baik yang ditimbulkan dalam diri sendiri ataupun dari luar. (Leila, 2002).

Jenis pekerjaan yang banyak diminati oleh masyarakat Indonesia saat ini yaitu, sektor informal pedagang kaki lima. Hidayat (1979), menjelaskan bahwa pedagang kaki lima sering dikatakan sebagai sektor sampah karena berkonotasi buangan bagi mereka yang gagal memasuki sektor formal, dan biasanya sektor ini berkaitan dengan kemiskinan dalam arti banyak diusahakan oleh golongan miskin. Dalam UU. No. 9 Tahun 1995 tentang usaha kecil, disebutkan bahwa pekerjaan usaha kecil dapat memperluas lapangan kerja dan berperanan dalam proses peningkatan pendapatan, serta mendorong pertumbuhan stabilitas ekonomi nasional. Menurut Asosiasi Pedagang Kaki Lima Indonesia (APKLI), mencatat pertumbuhan angka pedagang kaki lima tahun 2012 mencapai 9,8 juta atau naik sekitar 42 persen. (Tempo, 2012).

Di luar perkembangan pesatnya pedagang kaki lima juga memiliki ancaman tersembunyi, berupa ketegangan serta tekanan yang dapat tiba-tiba menyerang kesejahteraan hidup mereka. Hal tersebut, membuat para pedagang kaki lima mengalami berbagai tekanan psikologis yang berimbas terhadap keberlangsungan usaha yang mereka jalani. Fenomena job stress banyak terjadi di Indonesia. Beberapa studi terakhir menyimpulkan bahwa setiap tahunnya kasus job stress meningkat dengan cepat dan berpotensi menimbulkan dampak sosial, emosional, psikologis serta masalah yang berhubungan dengan kesehatan. Hasil studi dari Sartika, Masyitha dan Muhamad (2013), menemukan sebanyak $62.7 \%$ dari 75 responden teridentifikasi potensi stres kerja berat pada pedagang tradisional pasar Daya kota Makasar tahun 2013, karena disebabkan oleh faktor penghasilan yang mereka dapatkan setiap harinya.

Randal dan Elizabeth (1994), menjelaskan banyak masalah yang muncul berkaitan dengan stres, apalagi dalam kehidupan di kota besar yang sedemikian kompetitif dengan tekanan hidup semakin tinggi kemungkinan stres menjadi lebih besar, dibandingkan dengan orang yang hidup dalam situasi tenang, bahkan stres merupakan karakteristik kehidupan modern. Pekerjaan bisa menjadi sumber utama stres karena sebagian besar kegiatan orang-orang di kota besar dihabiskan untuk pekerjaan, pekerjaan menyita sebagai waktu hidup, bahkan merupakan kegiatan sentral di samping keluarga.

Gunarsa (2004), menjelaskan bahwa gejala yang mununjukan adanya gangguan stres yang terbagi dalam simptom fisik dan psikologis di antaranya adalah; stres sebagai pencetus penyakit kardiovaskuler, seperti ketegangan rasa pegal di bahu, pinggang, leher, kepala, dan gangguan sistem pencernaan (simptom fisik). Sedangkan stres sebagai 
pencetus penyakit ansietas, seperti perasaan tidak menentu, cemas, takut, ancaman dari luar. Seorang yang cemas, tertekan dan mudah depresi, bila tidak bisa mengatasi masalah maka akan merasa putus asa, bingung, apatis, sedih, susah tidur, pikiran negatif dan ketidakseimbangan emosi seperti; cepat marah, mudah berubah, cepat meluap, dan histeris (simptom psikologis).

Dalam persepektif kesehatan (K3), dapat dinyatakan bahwa tempat kerja merupakan tempat yang memungkinkan pekerja menghadapi resiko terganggunya kesehatan atau mengalami kecelakaan yang disebabkan oleh adanya berbagai bahaya yang ada ditemat kerja. (Anugrah, 2009).

Namun stres bukanlah sebuah momok yang menakutkan, gangguan stres pada tubuh tidak selalu berakibat negatif. Stres berderajat ringan atau normal justru diperlukan oleh manusia modern, karena seseorang memerlukan sistem peringatan diri pada tubuh. (Kompas, 1995). Menurut Rosch (2001), respon manusia terhadap stres terporsonalisasikan dan bervariasi bagi setiap individu. Apa yang dianggap stres oleh seseorang mungkin dianggap kesenangan oleh orang lain ataupun tidak membangkitkan respon sama sekali. Suatu peristiwa akan menimbulkan respon stres tergantung pada bagaimana peristiwa tersebut diinterpretasikan oleh individu, stres dapat dialami oleh situasi yang berbeda.

Untuk meminimalisir tingkat stres, dibutuhkan dukungan teman sejawat, keluarga dan masyarakat dalam mengurangi resiko kesehatan akibat tekanan pekerjaan. Selain dukungan dari luar dibutuhkan juga kemampuan internal individu dalam menghadapi stres, karena pada dasarnya individu sendiri tenyata memiliki kemampuan untuk meminimalisir job stress yang dirasakannya. Florian, Mikuliricer dan Taubman (1995), individu sendiri ternyata memiliki kemampuan untuk bisa mempengaruhi job stress yang dirasakannya. Paling tidak mereduksi apa yang dirasakan dan meminimalisir efek buruk yang dialami. Salah satu hal yang dapat mempengaruhi tinggi rendahnya job stress yang dirasakan adalah hardiness. Hardiness telah banyak dipertimbangkan sebagai suatu sikap mental yang dapat mengurangi efek stres secara fisik maupun mental pada individu.

Schultz dan Schultz (2002), menjelaskan bahwa individu yang memiliki tingkat hardiness yang tinggi, maka akan memiliki sikap yang membuat mereka lebih mampu dalam melawan stres. Individu dengan hardy personality, percaya bahwa mereka dapat mengontrol dan mempengaruhi kejadian-kejadian dalam hidupnya. Mereka secara mendalam berkomitmen terhadap pekerjaan dan aktivitas yang mereka senangi, mereka memandang perubahan sebagai sesuatu yang menarik dan menantang lebih dari pada sebagai sesuatu yang dihubungkan dengan tingkat stres yang tinggi.

Hasil penelitian yang dilakukan oleh Rahardjo (2005), bahwa terdapat hubungan yang negatif antara hardiness dengan job stress, yang artinya semakin tinggi hardiness yang dimiliki seseorang, maka akan semakin rendah job stress yang dirasakan. Begitupun sebaliknya, semakin rendah hardiness, maka akan semakin tinggi job stress yang dirasakan. Dalam penelitian lain, Eschleman, et.al. (2010), meneliti tentang aspek kepribadian hardiness serta hubungan antara hardiness dengan stres penelitiannya menunjukan bahwa hardiness berpengaruh secara positif yang diharapkan akan melindungi orang dari stres. 
Salah satu faktor yang diduga berpengaruh dengan terjadinya atau tidak terjadinya job stress adalah religiusitas. Mangkunegara (2000), berpendapat bahwa nilainilai agama dalam bentuk keimanan dan ketakwaan kepada Tuhan Yang Maha Esa merupakan pondasi yang paling utama, kecil kemungkinan akan memperoleh negatif dari stres ini secara lebih bermakna. Penelitian religiusitas juga dilakukan oleh Safaria (2011), menemukan bahwa religiusitas memainkan peranan penting dalam menurunkan atau menahan efek stressor kerja pada individu. Implikasinya, pengembangan keterampilan dan perilaku religius atau religious coping sangat dianjukan sebagai sebuah kekuatan bagi individu untuk menghadapi tuntutan job stress yang semakin meningkat.

Lazarus, Folkman (1984), dan Gibson (2006), menyatakan bahwa peristiwa yang melebihi sumber daya adaptif individu dapat menyebabkan munculnya distres serta respon negatif secara fisiologis, psikologis, dan perilaku. Sedangkan Pargament (1997), menjelaskan bahwa religiusitas juga dapat mempengaruhi respon kognitif untuk menangani peristiwa hidup yang negatif. (dalam Safaria et.al, 2010).

Berdasarkan paparan latar belakang di atas, pertanyaan yang muncul adalah, apakah semakin rendahnya hardiness individu yang dimiliki justru semakin sulit individu untuk meminimalisir job stress? atau sebaliknya, dikarenakan semakin tingginya hardiness yang muncul justru individu akan akan memiliki sikap yang membuat mereka lebih mampu dalam melawan job stress. Dan apakah semakin rendahnya religiusitas individu yang dimiliki justru semakin sulit individu untuk meminimalisir job stress? atau sebaliknya, dikarenakan semakin tingginya religiusitas individu akan memiliki sumber kekuatan untuk mengatasi tuntutan dalam meningkatnya job stress.

Oleh karena itu, penting masalah tersebut untuk diteliti lebih lanjut dengan objek pedagang kaki lima pasar pagi Sandratex kecamatan Ciputat kota Tangerang Selatan, yang tertuang dalam judul penelitian: "Pengaruh Hardiness dan Religiusitas Terhadap Job Stress Pedagang Kaki Lima Pasar Pagi Sandratex Kecamatan Ciputat Kota Tangerang Selatan".

\section{LANDASAN TEORI}

\section{Job Stress}

National Institute of Occupational Safety and Health (NIOSH), mendefinisikan job stress sebagai bahaya fisik dan emosional, tanggapan yang terjadi ketika persyaratan kerja tidak sesuai dengan kemampuan pekerja, sumber daya, dan kebutuhan. Definisi dari NIOSH menunjukkan bahwa job stress terjadi ketika kemampuan individu tidak bisa mengelola dan menangani tuntutan pekerjaan. Dalam persyaratan kata, orang dan pekerjaan lain tidak cocok dan sesuai, sehingga ketegangan dan frustrasi mempengaruhi individu secara emosional dan fisik. (dalam Safaria et.al, 2010).

Selanjutnya, menurut Beehr dan Newman (dalam Rout, 2002), mengatakan bahwa job stress dapat diartikan sebagai sumber atau stressor kerja yang menyebabkan reaksi individu berupa reaksi fisiologis, psikologis, dan perilaku. Menurut teori Beehr dan Newman (dalam Rout, 2002), menyebutkan ada tiga gejala yang diakibatkan stres, yaitu: 
1. Gejala fisiologis: yang terkait dengan aspek kesehatan dan medis yang dilihat dari perubahan metabolisme, meningkatnya laju detak jantung dan pernafasan, meningkatnya tekanan darah, menimbulkan sakit kepala, menyebabkan serangan jantung, tangan berkeringat, dan mual.

2. Gejala psikologis: dilihat dari ketidakpuasan, ketegangan, kecemasan, mudah marah, kebosanan, merasa kesepian, selera humor yang rendah, merasa bersalah. Kelelahan emosi adalah gejala psikologis seperti emosional (emotional exhaustion) dikarakteristikan dengan berkurangnya energi, kelelahan, dan perasaan bahwa sumber energi telah habis. Sinisme (depersonalization) diidentifikasikan dengan ketidak tertarikan pada pekerjaan dan memperlakukan orang lain sebagai objek bukan sebagai manusia. Berkurangnya efikasi (reduced personal accomplishment) mengacu kepada perasaan kurang percaya dengan kemampuannya dalam menyelesaikan pekerjaan dengan baik.

3. Gejala perilaku: dilihat dari perubahan produktivitas, perubahan kebiasaan makan, meningkatkan konsumsi rokok dan alkohol, bicara cepat, menggigit kuku, menggulung-gulung rambut.

\section{Hardiness}

Konsep hardiness pertama kali dikemukakan oleh Kobasa (1979). Menurut Kobasa hardiness adalah sebuah kumpulan dari beberapa karakteristik individu yang berfungsi sebagai sebuah sumber penolakan sebagai tameng dari kehidupan yang penuh stres. Konstruk ini merupakan komposisi dari tiga dasar pondasi elemen yang saling hubungan: comitmen, kontrol, dan tantangan.

Pendapat lain dari Kobasa (dalam Bartone, 2009), hardiness adalah sebagai gaya atau pola kepribadian terkait dengan kesehatan yang baik dan kinerja di bawah tekanan. Orang yang memiliki hardiness akan memiliki rasa hidup yang tinggi dan komitmen kerja, perasaan kontrol yang lebih besar atas apa terjadi pada mereka, dan lebih terbuka terhadap perubahan dan tantangan dalam hidup. dimensi yang dibangun oleh Maddi dan Kobasa (dalam Subramanian \& Vinothkumar, 2009) meliputi:

1. Komitmen (commitment): Komitmen, mencerminkan sejauh mana individu berusaha terlibat dalam aktivitas apapun, dari pada individu menarik diri. Komitmen, memiliki kualitas motivasi yang memaksa individu untuk bertahan dalam mengejar tujuan meskipun dalam kenyataannya hambatan terulang kembali.

2. Kontrol (control): Kontrol, berkaitan dengan sejauh mana individu berusaha untuk mengarahkan situasi mereka dari pada merasa tak berdaya. Persepsi seorang individu memandang sejauh mana stres terlihat penting dalam memahami ancaman.

3. Tantangan (challenge): Tantangan, mengukur sejauh mana individu berusaha untuk belajar dari pengalaman dari pada selalu merasa terancam.

\section{Religiusitas}

Dalam pengertian Glock dan Stark (dalam Ancok \& Suroso, 2005), agama atau religion adalah sistem simbol, sistem keyakinan, sistem nilai, dan perilaku yang 
terlambangkan yang semuanya berpusat pada personal yang dihayati sebagai yang paling maknawi (ultimate meaning).

Menurut Fetzer Institute (1999), religiusitas adalah perwujudan seberapa jauh individu yang menganut agama tertentu merasakan pengalaman beragama sehari-hari (daily spiritual experience), mencari makna dalam kehidupan (meaning), ekspresi keagamaan sebagai sebuah nilai (values), keyakinan (beliefs), memaafkan (forgiveness), melatih diri dalam beragama (private religious practice), coping stres dengan menggunakan pola dan metode berdo'a serta beribadah (religious/spiritual coping), hubungan sosial yang baik antara individu dengan pemuluk agama (religious support), individu berpartisipasi untuk agama selama hidupnya (religious/spiritual history), ikut serta dalam lembaga keagamaan (organizational religiousness), komitmen beragama (commitment), individu membuat pilihan dalam memastikan pilihan agamanya (religious preference). Dalam teori yang terdapat dalam Fetzer Institute (1999), terdapat 12 dimensi yaitu:

1. Dailly spiritual experience: Menurut Underwood, menjelaskan bahwa dimensi ini memandang dampak agama dan spiritual dalam kehidupan sehari-hari. Dailly spiritual experience merupakan persepsi individu terdapat sesuatu yang berkaitan dengan transenden dalam kehidupan dan persepsi terhadap interaksinya pada kehidupan tersebut, sehingga dailly spiritual experience lebih kepada pengalan kognitif.

2. Meaning: Menurut Pargament, meaning adalah mencari makna dalam kehidupan dan berbicara mengenai pentingnya makna atau tujuan hidup sebagai bagian dari rasa koberensi fungsi penting untuk mengatasi hidup atau unsur kesejahteraan psikologis. Konsep meaning dalam religiusitas sebagaimana konsep meaning yang dijelaskan oleh Fiktor Frank, yang biasa disebut dengan istilah kebermaknaan hidup. Adapun disebut religion meaning yaitu sejauh mana agama dapat menjadi tujuan hidupnya.

3. Values: Konsep values menurut Idler, values adalah pengaruh keimanan terhadap nilai-nilai kehidupan, seperti mengajarkan tentang nilai cinta, saling menolong, saling melindungi. Values dimaksud untuk mengukur dimensi berbeda dari nilai tempat keberadaan seseorang individu dalam agamanya.

4. Beliefs: Konsep beliefs menurut Idler, merupakan sentral dari religiusitas. Religiusitas merupakan keyakinan akan konsep-konsep yang di bawah oleh suatu agama. Dalam bahasa Indonesia beliefs disebut keimanan yaitu kebenaran yang diyakini dengan hati dan diamalkan dengan amal perbuatan. Keyakinan itu seperti yakin kepada Allah SWT, malaikat, kitab suci Al-Quran, Rasullah, hari akhir, dan qadha dan qadar.

5. Forgiveness: Konsep forgiveness menurut Idler, forgiveness adalah suatu tindakan memaafkan dan bertujuan untuk memaafkan bagi orang yang melakukan kesalahan dan berusaha keras untuk melihat orang itu dengan belas kasihan, kebajikan dan cinta.

6. Private relgious practice: Konsep private religious practice menurut Levin, yaitu menggambarkan kegiatan yang dilakukan oleh individu secara pribadi berbeda dengan public religious practice yang di lakukan formal, terorganisir dan berhubungan dengan orang lain yang melihat waktu dan tempat tertentu pada 
private religious practice tidak selalu terjadi pada tempat dan waktu yang pasti atau telah ditentukan.

7. Religious/spiritual coping: Religious/spiritual coping menurut Pargament, merupakan coping stres dengan menggunakan pola dan metode religiusitas, seperti berdo'a, dan beribadah.

8. Religious support: Konsep religious support menurut Krause, adalah aspek hubungan sosial antara individu dengan pemeluk agama sesamanya. Dalam Islam hal ini sering disebut dengan Al-Ukhuwah Al-Islamiyah.

9. Religious/spiritual history: Konsep religious/spiritual history menurut George, adalah seberapa jauh individu berpartisipasi untuk agama selama hidupnya dan seberapa jauh agama mempengaruhi perjalanan hidupnya. Pengukuran hal ini dimaksudkan untuk mengukur sejauhmana keberagamaan.

10. Commitment: Konsep commitment menurut Williams, adalah seberapa jauh individu mementingkan agamannya, berkomitmen, serta berkontribusi kepada agamanya.

11. Organizational religiousness: Konsep organizational religiousness menurut Idler, merupakan konsep yang mengukur seberapa jauh individu ikut serta dalam lembaga keagamaan yang ada di masyarakat dan beraktivitas di dalamnya.

12. Religious preference: Konsep religious preference menurut Ellison, yaitu memandang sejauh mana individu membuat pilihan dalam memastikan pilihan agamanya.

\section{METODE PENELITIAN}

Berdasarkan tujuan penelitian, maka populasi pada penelitian ini adalah pedagang kaki lima pasar pagi Sandratex kecamatan Ciputat kota Tangerang Selatan, yang berjualan setiap hari Sabtu dan Minggu, pukul: 06.00 - 11.00 WIB. Gambaran populasi berdasarkan hasil survey yang dilakukan peneliti, pada tanggal 4 Mei 2013 di pasar pagi Sandratex, terdapat kurang lebih 145 orang pedagang kaki lima.

Alat ukur yang digunakan untuk mengukur Job stress diukur berdasarkan teori Beehr dan Newman (dalam Rout, 2002), yang menyebutkan tiga gejala yang diakibatkan stres yaitu gejala fisiologis, gejala psikologis dan gejala perilaku, yang terdiri dari 17 item.

Skala hardiness yang disusun oleh peneliti sendiri dengan mengadaptasi skala hardiness berdasarkan teori Maddi dan Kobasa (dalam Subramanian \& Vinothkumar, 2009). Skala hardiness yang dirancang untuk mengukur komponen hardiness yang terdiri dari tiga dimensi yaitu: kontrol, komitmen, dan tantangan. Peneliti juga menggunakan skala pengukuran Bell (dalam, Funk \& Houston,

1987), skala tersebut digunakan untuk item penambahan dalam penelitian ini. diakibatkan stres yaitu gejala fisiologis, gejala psikologis dan gejala perilaku, yang terdiri dari 18 item.

Fetzer Institute (1999), pengukuran skala religiusitas terdapat dua belas dimensi yaitu: dailly spiritual experience, maining, values, beliefs, forgiveness, private religious practice, religious/spiritual coping, religious support, religious/spiritual history, commitment, organizational religiousness, dan religious preference. diakibatkan stres yaitu gejala fisiologis, gejala psikologis dan gejala perilaku, yang terdiri dari 62 item. 


\section{HASIL PENELITIAN}

Dari hasil analisis berganda, diperoleh $R 2$ sebesar Dengan demikian, dapat disimpulkan bahwa dari lima belas variabel independen, hanya ada empat variabel independen yang kontribusinya signifikan terhadap variabel dependen (job stress), yaitu variabel religious preference $36.2 \%$, variabel religious/spiritual coping $3.6 \%$, variabel religious/spiritual history $2.5 \%$, dan variabel commitment $1.9 \%$. 
Tabel 1

Koefisien regresi

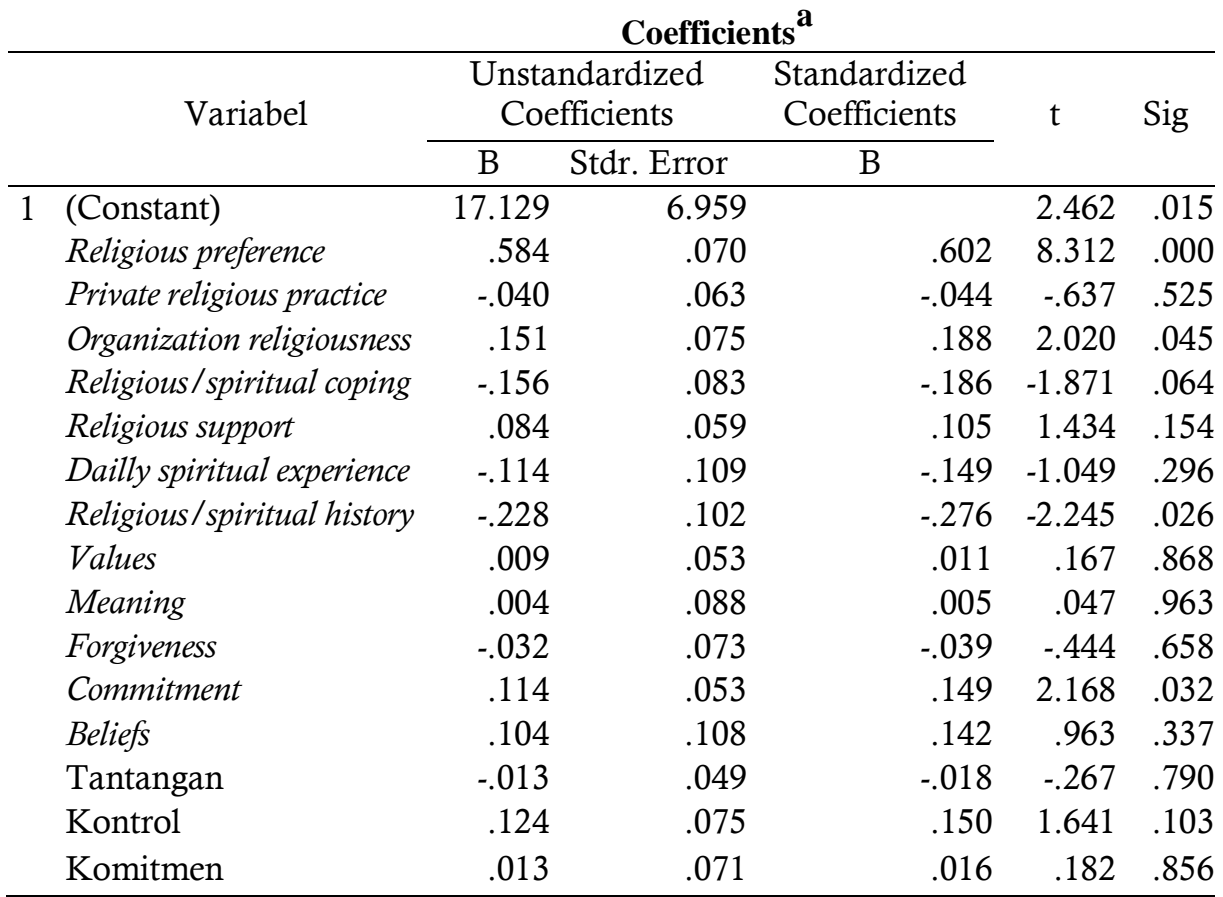

a. Dependent Variable: Job stress

Dari tabel 1 di atas dapat dilihat bahwa religious preference, organization religiousness, religious/spiritual history dan commitment memiliki nilai $\mathrm{p}<0.05$ sehingga keempat IV tersebut signifikan. Sedangkan yang lainnya memiliki $\mathrm{p}>0.05$ yang artinya tidak signifikan. dapat dilihat dari 15 variabel independen, hanya 4 yang memiliki pengaruh terhadap job stress secara signifikan. Pertama, untuk variabel religious preference $(\beta=0.00$, $\mathrm{p}<0.05)$. Artinya variabel religious preference secara positif dan signifikan mempengaruhi job stress. Jadi semakin rendah religious preference maka semakin rendah pula job stress. Kedua, variabel organization religiousness $(\beta=0.045, \mathrm{p}<0.05)$. Artinya organization religiousness secara positif dan signifikan mempengaruhi job stress. Jadi semakin rendah organization religiousness maka semakin rendah job stress. Ketiga, variabel religious/spiritual history $(\beta=0.026, \mathrm{p}<0.05)$. Artinya variabel religious/spiritual history secara negatif dan signifikan mempengaruhi job stress. Jadi semakin rendah religious/spiritual history maka semakin rendah pula job stress. Keempat, variabel commitment $(\beta=0.032, \mathrm{p}<0.05)$. Artinya variabel commitment secara positif dan signifikan mempengaruhi job stress. Jadi semakin rendah commitment maka semakin rendah pula kepuasan kerja. 
Tabel 2

Proporsi varian

\begin{tabular}{|c|c|c|c|c|}
\hline \multirow{3}{*}{ Variabel } & \multicolumn{4}{|c|}{ Change Statistics } \\
\hline & \multirow{2}{*}{\multicolumn{2}{|c|}{ R Square R Square Change }} & F Change & \multirow{2}{*}{$\begin{array}{c}\text { Sig. } \\
\text { F Change }\end{array}$} \\
\hline & & & df1 & \\
\hline Religious preference & .362 & .362 & $81.059(1,143)$ & .000 \\
\hline Private religious practice & .362 & .000 & $.085(1,142)$ & .771 \\
\hline Organizational religiousness & .365 & .003 & $.708(1,141)$ & .401 \\
\hline Religious/spiritual coping & .404 & .038 & $9.003(1,140)$ & .003 \\
\hline Religious support & .407 & .003 & $.676(1,139)$ & .412 \\
\hline Dailly spiritual experience & .407 & .000 & $.023(1,138)$ & .878 \\
\hline religious/spiritual history & .431 & .025 & $5.947(1,137)$ & .016 \\
\hline Values & .433 & .002 & $.416(1,136)$ & .520 \\
\hline Maining & .435 & .002 & $.516(1,135)$ & .474 \\
\hline Forgiveness & .436 & .001 & $.152(1,134)$ & .698 \\
\hline Commitment & .455 & .019 & $4.601(1,133)$ & .034 \\
\hline Beliefs & .461 & .007 & $1.630(1,132)$ & .204 \\
\hline Tantangan & .462 & .001 & $.123(1,131)$ & .727 \\
\hline Kontrol & .477 & .015 & $3.765(1,130)$ & .055 \\
\hline Komitmen & .477 & .000 & $.033(1,129)$ & .856 \\
\hline
\end{tabular}

Pengujian proporsi varians untuk masing-masing variabel independen menunjukan bahwa:

1. Variabel dimensi religious preference memberikan sumbangan sebesar $36.2 \%$ terhadap job stress dan secara statistik signifikan, dengan nilai $\mathrm{F}$-change sebesar 0.000 (sig. $<0.05$ ).

2. Variabel dimensi private religious practice memberikan sumbangan sebesar $0 \%$ terhadap job stress dan secara statistik tidak signifikan, dengan nilai $\mathrm{F}$ change sebesar 0.771 (sig. $>0.05$ ).

3. Variabel dimensi organizational religiousness memberikan sumbangan sebesar $0.3 \%$ terhadap job stress dan secara statistik tidak signifikan, dengan nilai $\mathrm{F}$ change sebesar 0.401 (sig.>0.05).

4. Variabel religious/spiritual coping memberikan sumbangan sebesar 3.8\% terhadap job stress dan secara statistik signifikan, dengan nilai $\mathrm{F}$ change sebesar 0.003 (sig.<0.05).

5. Variabel dimensi religious support memberikan sumbangan sebesar $0.3 \%$ terhadap job stress dan secara statistik tidak signifikan, dengan nilai $\mathrm{F}$ change sebesar 0.412 (sig. $>0.05)$

6. Variabel dimensi dailly spiritual experience memberikan sumbangan sebesar $0 \%$ terhadap job stress dan secara statistik tidak signifikan, dengan nilai $\mathrm{F}$ change sebesar 0.878 (sig. $>0.05$ ).

7. Variabel dimensi religious/spiritual history memberikan sumbangan sebesar $2.5 \%$ terhadap job stress dan secara statistik signifikan, dengan nilai $\mathrm{F}$ change sebesar 0.016 (sig.<0.05). 
8. Variabel dimensi values memberikan sumbangan sebesar $0.2 \%$ terhadap job stress dan secara statistik tidak signifikan, dengan nilai $F$ change sebesar 0.520 (sig. $>0.05$ ).

9. Variabel dimensi maining memberikan sumbangan sebesar $0.2 \%$ terhadap job stress dan secara statistik tidak signifikan, dengan nilai $F$ change sebesar 0.474 (sig.>0.05).

10. Variabel dimensi forgiveness memberikan sumbangan sebesar $0.1 \%$ terhadap job stress dan secara statistik tidak signifikan, dengan nilai $\mathrm{F}$ change sebesar 0.698 (sig.>0.05).

11. Variabel dimensi commitment memberikan sumbangan sebesar $1.9 \%$ terhadap job stress dan secara statistik signifikan, dengan nilai F change sebesar 0.034 (sig. $<0.05)$.

12. Variabel dimensi beliefs memberikan sumbangan sebesar $0.7 \%$ terhadap job stress dan secara statistik tidak signifikan, dengan nilai F change sebesar 0.204 (sig.>0.05).

13. Variabel dimensi tantangan memberikan sumbangan sebesar $0.1 \%$ terhadap job stress dan secara statistik tidak signifikan, dengan nilai $\mathrm{F}$ change sebesar 0.727 (sig.>0.05).

14. Variabel dimensi kontrol memberikan sumbangan sebesar 1.5\% terhadap job stress dan secara statistik tidak signifikan, dengan nilai $F$ change sebesar 0.055 (sig. $>0.05$ ).

15. Variabel dimensi komitmen memberikan sumbangan sebesar $0 \%$ terhadap job stress dan secara statistik tidak signifikan, dengan nilai $\mathrm{F}$ change sebesar 0.856 (sig.>0.05).

\section{KESIMPULAN}

Berdasarkan hasil analisa data serta pengujian hipotesis yang telah dikemukakan pada bab sebelumnya, maka kesimpulan yang dapat diambil dari penelitian ini adalah variabel hardiness dan religiusitas secara bersama-sama berpengaruh signifikan terhadap job stress, akan tetapi dimensi variable hardiness (komitment, kontrol, dan tantangan) tidak menunjukan pengaruh signifikan. Sedangkan dimensi variabel religiusitas yang berpengaruh signifikan yaitu dimensi religious preference, religious/spiritual history, commitment, dan organizational religiousness. Variabel religiusitas yang tidak berpengaruh signifikan yaitu religious/spiritual coping, religious support, dailly spiritual experience, beliefs, private religious practice, forgiveness, values, dan maining.

Berikut ini adalah urutan variabel independen yang memiliki pengaruh terkuat hingga yang terlemah: religious preference, religious/spiritual history, commitment, organizational religiousness, religious/spiritual coping, kontrol, religious support, dailly spiritual experience, beliefs, private religious practice, forgiveness, tantangan, komitmen, values, maining. Religious preference merupakan variabel independen yang memiliki pengaruh yang paling kuat terhadap job stress dan seterusnya sehingga maining sebagai variabel independen yang memiliki pengaruh paling lemah terhaap job stress.

\section{DISKUSI}


Dari hasil penelitian ini, variabel hardiness (komitmen, kontrol, dan tantangan), tidak ditemukan berpengaruh yang signifikan terhadap job stress pada pedagang kaki lima. Variabel komitmen tidak mempengaruhi secara signifikan. Hal ini bertentangan dengan pendapat Kobasa \& Maddi (1982), yang menjelaskan bahwa komitmen adalah kebutuhan untuk terlibat, berkontribusi, bertanggung jawab, membantu untuk orang lain. Umumnya individu yang berkomitmen memiliki pemahaman yang bertujuan untuk tidak menyerah di bawah tekanan, dan termotivasi dalam mencapai tujuan, karena cenderung menginvestasikan diri mereka sendiri dalam situasi tertekan sekalipun. Orang yang berkomitmen biasannya mengikat terhadap lingkungan secara aktif dan mendekat dari pada pasif dan menghindar.

Selanjutnya, variabel kontrol tidak mempengaruhi secara signifikan, hal ini bertolak belakang dengan teori Kobasa \& Maddi (1982), yang menjelaskan bahwa kontrol mengacu pada keyakinan bahwa seseorang dapat mengendalikan atau mempengaruhi kejadian dalam kehidupannya, sehingga dengan kontrol yang baik, stres dapat dikurangi atau dimodifikasi menjadi keadaan yang lebih mudah untuk dikelola karena individu mampu mengarahkan kejadian yang penuh dengan stres. Orang yang memiliki ciri ini lebih cenderung meramalkan peristiwa yang penuh stres sehingga dapat mengurangi keterbukaan mereka pada situasi yang menghasilkan kegelisahan. Lebih lanjut dengan kontrol juga individu mencari kejelasan mengapa sesuatu sedang terjadi, tidak hanya dalam kaitan dengan lain tindakan, tetapi juga dengan satu penekanan tanggung jawab milik mereka sendiri. Individu memiliki kecenderungan untuk percaya dan bertingkah laku sebagai salah satu faktor belajar dari peristiwa. (Sciaccchitano, et.al, 2001).

Selanjutnya variabel tantangan tidak berpengaruh secara signifikan, hal ini bertolak belakang dengan teori Kobasa \& Maddi (1982), yang menjelaskan bahwa, dimensi ini mencerminkan keyakinan bahwa perubahan bukanlah ancaman bagi keamanan pribadi, melainkan kesempatan untuk terus tumbuh dan berkembang. Sikap positif ini menunjukan keyakinan seseorang yang mampu mendapatkan keuntungan dari kegagalan menjadi sebuah keberhasilan dan belajar dari pengalaman.

Hasil penelitian ini juga bertolak belakang dengan penelitian Florian, Mikuliricer dan Taubman (Rahardjo, 2005), yang menunjukan ada pengaruh yang signifikan pada variabel hardiness terhadap job stress,yang menjelaskan bahwa individu yang memiliki hardy personality yang tinggi maka akan memiliki sikap yang membuat mereka lebih mampu dalam melawan stres. Karena hardiness juga telah banyak dipertimbangkan sebagai suatu sikap mental yang dapat mengurangi efek stres secara fisik maupun mental pada individu. Kreitner dan Kinicki (2005), menjelaskan tingginya job stress pada subjek penelitian disebabkan rendahnya kepribadian hardiness yang dimiliki oleh subjek penelitian. Karena pekerja yang tahan banting akan mampu bertahan dalam situasi yang mendesak, dalam menghadapi tuntutan dan tantangan pekerjaan yang menimbulkan stres di tempat kerja, dan sebaliknya pekerja yang memiliki kepribadian hardiness yang rendah akan mudah menyerah dan putus asa dalam menghadapi masalah dan sering kali merasa kesulitan dalam menghadapi situasi-situasi yang menekan yang dapat menjadi stressor. Selanjutnya, hasil penelitian ini juga tidak sejalan dengan pendapat Maddi dan Kobasa (1982), yang menyebutkan bahwa saat dihadapkan pada stressor yang menekan, individu yang memiliki kepribadian hardiness 
bukan mengalami suatu yang menekan, tapi suatu hal yang menarik dan penting (komitmen), minimal suatu yang dapat mempengaruhi (kontrol), dan sebagai nilai yang berpotensi mengembangkan diri (tantangan). Dengan menginterpretasikan stressor sebagai suatu yang menantang dan tidak berbahaya dan individu tidak merasa stres dan akan selalu berfikir positif terhadap kejadian yang mengancam.

Dari penjelasan di atas, dimensi dari variabel hardiness tidak menunjukan pengaruh signifikan, hal tersebut bisa saja karena rendahnya job stress yang dimiliki subjek penelitian, yang sebagian tergambar dalam katagorisasi rendahnya variabel hardiness terhadap job stress. Selanjutnya yang membuat variabel tidak berpengaruh signifikan adalah rendahnya tingkat kepribadian hardiness sendiri yang dimiliki oleh subjek penelitian. Lebih jelas lagi variabel hardiness dalam penelitian biasannya digunakan subjek pekerja formal atau karyawan perusahaan yang memiliki sistem organisasi dan aturan dalam bekerja untuk memenuhi target produksi, sedangkan variabel hardiness dalam penelitian ini digunakan subjek non perusahaan yaitu pedagang kaki lima yang tidak memiliki aturan dan tekanan target untuk produksi.

Variabel hardiness dalam penelitian ini mengukur tingkat kepribadian tahan banting pedagang kaki lima dalam menghadapi tekanan dan ancaman dalam bekerja seperti daya saing sesama pedagang kaki lima, pendapatan, tekanan penggusuran, dan lain-lain. Jadi jelas bahwa variabel hardiness lemah dalam penelitian ini dikarenakan memang rendahnya job stress dan hardiness yang dimiliki oleh pedagang kaki lima.

Selanjutnya variabel yang diteliti dalam penelitian ini adalah variabel religiusitas, religiusitas memiliki dua belas dimensi yaitu, dailly spiritual experience, maining, values, beliefs, forgiveness, private religiosnuss practice, religious/spiritual coping, religious support, religious/spiritual history, commitment, organizational religiousness, dan religious preference. Secara keseluruhan religiusitas mempengruhi job stress, namun dari dua belas dimensi religiusitas hanya empat variabel independen yang berpengaruh signifikan. Hasil penelitian ini sejalan dengan penelitian Safaria, et.al. (2010), yang menjelaskan bahwa religiusitas dapat meminimalisir job stress yang dialami oleh pekerja.

Variabel religious preference, menunjukan pengaruh yang signifikan, hal ini sependapat dengan teori Chritopher Ellison (dalam Rusdi, 2012), yang menjelaskan bahwa sejauh mana kepastian individu dalam meyakini tradisi agamannya atau sejauh mama individu agama menjadi identik bagi dirinya. Mengapa seseorang kecil tingkat stres yang dialaminya karena mereka biasa membangun jaringan sosial antara umat beragama dan tetap berpedoman dalam tradisi agamanya.

Selanjtnya variabel religious/spiritual history, menunjukan pengaruh yang signifikan, hal ini sependapat dengan teori Linda George (dalam Rusdi, 2012), semakin seseorang berpartisipasi dalam hidupnya untuk agama baik pendidikan agamanya, kematangan agama, kegiatan agama, perubahan hidup keagamaan dan menjadikan agama yang bersifat eksternal menjadi lebih internal maka akan memberikan dampak positif terhadap kesehatan mental termasuk pada job stress.

Selanjutnya variabel commitment, menunjukan pengaruh yang signifikan, hal ini bertentangan dengan penelitian Rusdi (2012), yang tidak menemukan korelasi yang signifikan antara commitment terhadap kesehatan mental seseorang.

Selanjutnya variabel organizational religiousness menunjukan pengaruh yang signifikan, hal ini sependapat dengan teori We Chun Chang (dalam Rusdi, 
2012), menjelaskan bahwa keikutsertaan seseorang dalam beragama memiliki korelasi yang signifikan dengan kepuasan dan kebahagian hidup yaitu hidupnya banyak kenikmatan dan kecukupan yang didapat. Dalam hal ini jika kebahagian hidup selalu ada pada seeorang maka semakin kecil kesulitan dan stres yang mereka alami.

Selanjutnya variabel religious/spiritual coping tidak berpengaruh signifikan, hasil penelitian ini bertolak belakang dengan hasil penelitian oleh Safaria et.al, (2010), yang menyatakan bahwa pada saat stres, banyak orang melihat ke agama

mereka sebagai coping untuk membantu dalam menghadapi serta upaya untuk menjaga bagaimana yang individu temukan berpengaruh dalam kehidupan, karena agama menawarkan berbagai cara untuk mengatasinya. Ketika individu dengan religious/spiritual coping tinggi, maka dampak dari ketidakamanan kerja terhadap stres akan menurun. Sebaliknya ketika individu dengan religious/spiritual coping rendah, pekerja merasa tidak aman, maka efek dari ketidakamanan kerja mengalami peningkatan stres akan meningkat.

Selanjutnya variabel daily spiritual experience tidak berpengaruh signifikan, hal ini bertentangan dengan penjelasan Koing (Fetzer Institute, 1999), karena pada dasarnya bahwa individu yang mampu menciptakan emosi positif, perasaan positif tentang agama dapat mencegah individu yang ingin terlibat dalam perilaku menyenangkan tapi yang membahayakan kesehatan.

Selanjutnya variabel forgiveness tidak berpengaruh signifikan, hal ini berbeda dengan apa yang dijelaskan oleh Dr. Frederic Luskin (dalam Ismirani, 2011), dalam bukunya yang berjudul "Forgive For Good", bahwa sikap pemaaf sebagai resep yang telah terbukti bagi kesehatan dan kebahagiaan. Buku tersebut juga memaparkan bagaimana sifat pemaaf akan memicu terciptannya keadaan lebih baik seperti harapan, kesabaran, dan percaya diri dengan mengurangi kemarahan, penderitaan dan stres.

Selanjutnya variabel beliefs, dalam penelitian ini menunjukan pengaruh positif namun tidak signifikan, secara psikologis, keyakinan agama dan spiritual dapat dipahami, menurut Carone dan Barone (Fetzer Institute, 1999) sebagai bagian dari bagaimana menafsirkan dunia, bagaimana individu membentuk ide, dan bagaimana individu menilai dunia.

Selanjutnya variabel religious support, dalam penelitian ini menunjukan pengaruh positif namun tidak signifikan, dalam hal ini umat agama jika bergandeng tangan penuh dengan kedamaiaan dan saling menghormati maka akan terhindar dari gesekangesekan yang akan mengakibatkan pertentangan, permusuhan, dan perpecahan yang dapat memicu timbulnya stres.

Selanjutnya, dimensi religiusitas yang hasilnya bertolak belakang dengan teori, mungkin saja karena individu belum benar-benar menginternalisasi nilai agama setiap saat, karena pada dasarnya Allah SWT, meminta individu untuk mengingatnya disetiap saat. Agar qolbu ini dapat dijauhkan dari keresahan dan mendapatkan ketenangan. Seseorang tidak bisa menghindari stres dalam kehidupan ataupun hidup tanpa stres, hal ini penting dalam tahap perkembangan manusia, namun apabila berlebihan hal ini dapat merusak tubuh manusia, meminimalkan stres dalam batas toleransi seseorang merupakan tujuan terapi religiusitas dan psikologi. 
Secara keseluruhan, peneliti berasumsi bahwa perbedaan dan ketidaksesuaian antara hasil penelitian terdahulu ini bisa diakibatkan oleh beberapa hal baik sampel, tempat penelitian, maupun alat ukur yang digunakan. 


\section{DAFTAR PUSTAKA}

Ancok, D., \& Suroso F.N. (1994). Psikologi Islam: Solusi Islam atas problem-problem psikologi. Yogyakarta: Pustaka Pelajar.

Bartone, P.T., Eid, J., Johnsen, B.H., Lamberg, J.C., \& Snook, S.A. (2009). Big five personality factors, hardiness, and social judgment as predictors of leader performance. Leadership \& Organization Development Journal. Emerald Group Publishing Limited. Vol.30 (6), 498-521. Doi: 10.1108/01437730910981908.

Idler, EL. (1999). Organizational religiousness. (dalam Fetzer Institute \& National Institute on Aging Working Group, 1999). 75-80. Multidimensional Measurement of Religiousness/ Spirituality for Use in Health. Diunduh 21 Januari 2012 dari http://www.google.com/http://www.gembeta.org/public/Download-Measure.

Idler, EL. (1999). Forgiveness. (dalam Fetzer Institute \& National Institute on Aging Working Group, 1999). 35-37. Multidimensional Measurement of Religiousness/ Spirituality for Use in Health. Diunduh 21 Januari 2012 dari Error! Hyperlink reference not valid.public/Download-Measure.

Idler, EL. (1999). Beliefs. (dalam Fetzer Institute \& National Institute on Aging Working Group, 1999). 31-33. Multidimensional Measurement of Religiousness/ Spirituality for Use in Health. Diunduh 21 Januari 2012 dari http://www.google.com/ http://www.gembeta.org/public/Download-Measure.

Idler, EL. (1999). Values. (dalam Fetzer Institute \& National Institute on Aging Working Group, 1999). 25-27. Multidimensional Measurement of Religiousness/ Spirituality for Use in Health. Diunduh 21 Januari 2012 dari http://www.google.com/ http://www.gembeta.org/public/Download-Measure.

Ellison, C.G. (1999). Religious preference. (dalam Fetzer Institute \& National Institute on Aging Working Group, 1999). 81-84. Multidimensional Measurement of Religiousness/ Spirituality for Use in Health. Diunduh 21 Januari 2012 dari http://www.google.com/http://www.gembeta.org/public/Download-Measure.

Fetzer Institute \& National Institute on Aging Working Group (1999).

Multidimensional measurement of religiousness/ spirituality for use in health._1-95. $\begin{array}{lllll}\text { Diunduh } & 21 & \text { Januari } & 2012 & - \text { dari }\end{array}$ http://www.google.com/http://www.gembeta.org/ public/Download-Measure.

Funk, S.T., \& Houston B.K. (1987). A critical analysis of the hardiness scale's validity and utility. Journal of Personality and Social Psychology. Vol.53 (3), 572-578. Doi:0022-3514/87/500.75.

George L.K. (1999). Religious/spiritual history. (dalam Fetzer Institute \& National Institute on Aging Working Group, 1999). 65-69. Multidimensional Measurement of Religiousness/ Spirituality for Use in Health. Diunduh 21 Januari 2012 dari http://www.google.com/http://www.gembeta.org/public/Download-Measure.

Hidayat, (1979). Sektor informal dalam struktur ekonomi Indonesia (dalam profil Indonesia) Jakarta: Lembaga Studi Pembangunan. 
Krause, N. (1999). Religious support. (Dalam Fetzer Institute \& National Institute on Aging Working Group, 1999). 57-63. Multidimensional Measurement of Religiousness/ Spirituality for Use in Health. Diunduh 21 Januari 2012 dari http://www.google.com/http://www.gembeta.org/public/Download-Measure.

Kobasa, S. C. (1982). Hardiness and Health : A Prospective Study. Journal of Personality and Social Psychology, Vol. 42 (1), 168-177. Diunduh pada tanggal 20 Maret 2013 dari psycnet.apa.org/journals/psp/42/1/168/.

Kreitner, R. \& Kinicki, A. (2005). Perilaku Organisasi. Buku 2. Edisi 5. Alih Bahasa: Erly Suandy. Jakarta: Salemba Empat

Levin, J. (1999). Private religious practices. (Dalam Fetzer Institute \& National Institute on Aging Working Group, 1999). 39-42. Multidimensional Measurement of Religiousness/ Spirituality for Use in Health. Diunduh 21 Januari 2012 dari http://www.google.com/http://www.gembeta.org/public/Download-Measure.

Manning \& Tajudin, (1991). Urbanisasi pengangguran sektor informal di kota, PPSK UGM. Jakarta: Yayasan Obor Indonesia.

Pergament, K.I. (1999). Religious/ spiritual coping. (dalam Fetzer Institute \& National Institute on Aging Working Group, 1999). 43-50. Multidimensional Measurement of Religiousness/ Spirituality for Use in Health. Diunduh 21 Januari 2012

dari

http://www.google.com/http://www.gembeta.org/public/Download-Measure.

Pergament, K.I. (1999). Meaning. (dalam Fetzer Institute \& National Institute on Aging Working Group, 1999). 19-23. Multidimensional Measurement of Religiousness/ Spirituality for Use in Health. Diunduh 21 Januari 2012 dari http://www.google.com/http://www.gembeta.org/public/Download-Measure.

Rahardjo, W. (2005). Pengaruh hardiness dan self efficacy terhadap stres kerja (studi) pada Perawat RSP DR. Soeradji Tirtonegoro Klaten. Universitas Gunadarma Depok. Diunduh pada tanggal 25 Maret 2013 dari http://eprints.undip.ac.id/10782/1/\%28jurnal\%29- andreas agung k.pdf.

Rout, U.R., \& Rout, J.K. (2002). Stress management for primary health care professionals. New York: Kluwer Academic Plublihers. Diunduh pada tanggal 27 Februari 2013 dari http://www.amazon.com/Stress-ManagementPrimary-Health Professionals/ dp/0306472406.

Rusydi, A. (2012). Religiusitas dan kesehatan mental: Studi pada jama'ah tabligh Jakarta Selatan. Jakarta: Young Progressive Muslim.

Safaria, T., Othman, A.B., \& Wahab, M.B.A. (2010). Religious coping, job insecurity and job stress among Javanese academic staff: A moderated regression analysis. International Journal of Psychological Studies. Malaysia: University Malaysia Pahang. No.090123, 160-161. Diunduh pada tanggal 26 Februari 2013 dari http://www.ccsenet.org/journal/index. php/ijps/article/view/8520.

Safaria, T. (2011). Peran religious coping sebagai moderator dari job insecurity terhadap stres kerja pada staf akademik. Fakultas Psikologi Universitas Ahmad Dahlan Jakarta. Jurnal Humanitas. Vol.8 (2), 157-158. Diunduh 26 pada tanggal Februari $2013 \quad$ dari http://journal.uad.ac.id/index.php/ humanitas/article/view/239. 
Sartika, D.M., Masyitha, M., \& Muhamad, R.R. (2013). Faktor yang berhubungan dengan stres kerja pada pedagang tradisional pasar daya kota makasar tahun 2013

Schultz, D. \& Schultz, S.E. (2002). Psychology and Work Today an Introduction to Industrial and Organizational Psychology. Ninth Edition. University of Florida : Pearson Education Inc.

Subramanian, S. \& Vinothkumar, M. (2009). Hardiness personality, self esteem and occupational stress among IT professionals. Journal of the Indian Academy of Applied Psychology. Vol.35, 48-56. Diunduh pada tanggal 2 Maret 2013 dari http://medind.nic.in/jak/t09/s1/jakt09s1p48.pdf.

Sururin. (2004). Ilmu jiwa agama. Jakarta: PT. Raja Grafindo Persada. Underwood, L.G. (1999). Daily spiritual experience. (dalam Fetzer

Institute \& National Institute on Aging Working Group, 1999). 11-18. Multidimensional Measurement of Religiousness/Spirituality for Use in Health. Diunduh $21 \quad$ Januari $2012 \quad$ dari http://www.google.com/http://www.gembeta.org/public/Download-Measure.

Florian, M. Mikulincer \& Taubman (1995). Does Hardiness Contribute to Mental Health During a Stressful Real-Life Situation? The Role Of Appraisaland Coping. Journal of Personality and Social Psychology. Vol.68 (4), 687-695 $\begin{array}{llllll}\text { Diunduh } & \text { pada tanggal } 2014 & \text { Mei }\end{array}$ psycnet.apa.org/index.cfm?fa=buy.optiontobuy\&id.pdf.

William, D.R. (1999). Commitmnet. (dalam Fetzer Institute \& National Institute on Aging Working Group, 1999). 71-74. Multidimensional Measurement of Religiousness/ Spirituality for Use in Health. Diunduh 21 Januari 2012 dari http://www.google.com/http:// www.gembeta.org/public/Download-Measure. 